Hansen, B. T. \& Steiger, R. H. 1971: The geochronology of the Scoresby Sund area. Progress report I: $\mathrm{Rb} / \mathrm{Sr}$ mineral ages. Rapp. Gronlands geol. Unders. 37, 55-57.

Henriksen, N. \& Higgins, A. K. 1970: Preliminary results of mapping in the crystalline complex of Renland, the southern Stauning Alper and south-west Liverpool Land, Scoresby Sund, East Greenland. Rapp. Grønlands geol. Unders. 30, 5-17.

Kranck, E. H. 1935: On the crystalline complex of Liverpool Land. Meddr Grønland 95, 7, $122 \mathrm{pp}$.

Noe-Nygaard, A. 1937: Die palaeozoischen Eruptivgesteine von Canning Land. Meddr Grønland 118, 6, $153 \mathrm{pp}$.

\title{
FIELD MAPPING OF PALAEOZOIC, MESOZOIC AND TERTIARY SEDIMENTS IN THE SCORESBY SUND REGION, EAST GREENLAND
}

\author{
Tove Birkelund and Katharina Perch-Nielsen
}

An eight-week field season concluded the four-year mapping project on the Phanerozoic sediments of the Scoresby Sund region. Six teams worked in Scoresby Land, Jameson Land, Liverpool Land and the Kap Brewster area (see Henriksen, this report). In addition to the authors the following took part in the 1971 mapping: R. G. Bromley, U. Asgard, F. Surlyk (Univ. of Copenhagen), M. Aellen (Eidg. Techn. Höchschule, Zurich), J. H. Callomon (Univ. of London) and K. Birkenmajer (Polish Acad. Sci., Krakow).

In Scoresby Land one party revised the map of Gurreholm Bjerge, printed but not yet published, which was prepared by $M$. Aellen. Here the Upper Permian locality with Cyclolobus found in 1957 by Aellen, was revisited and new material collected. At this locality, the Upper Permian-Lower Triassic boundary is rather indistinct. Special attention was paid to the Triassic red beds, gypsum and sedimentary structures. A paper by Perch-Nielsen, Birkenmajer, Birkelund and Aellen on the revised stratigraphical subdivision of the Triassic sequence is in preparation. Short visits were paid to scattered localities in both Scoresby Land and Jameson Land to fill gaps in the previous years' mapping.

On Wegener Halvø the map by Grasmïck and Trümpy (1969) was revised. Sediments of the Eleonore Bay Group and the Devonian Cape Fletcher volcanics were found along Fleming Fjord in the middle part of the peninsula faulted against Devonian sandstones and siltstones. The Upper Permian overlies the folded and faulted Devonian with an angular unconformity that can be observed in several places. A polygenetic basal conglomerate to breccia occurs locally at the base of the Upper Permian limestones. The overlying, dark Posidonia shales are only present in small basins between reefs and are overlain by limestones with 
brachiopods, bryozoans and echinoderms. Locally these limestones contain large amounts of clastic material or are interbedded with coarse, white sandstones. Upper Permian or Lower Triassic erosion removed parts of this Upper Permian succession, the hiatus being more marked towards the east. Special attention was paid to coarser clastic intercalations in the shales of the Triassic Wordie Creek Formation that can be locally used as correlation horizons.

Along Carlsberg Fjord and in Klitdal parts of the map prepared by Callomon in 1959 (see Callomon, 1970) were revised and areas not hitherto visited were mapped. Detailed studies of trace fossils were made in the red beds, especially in the Malmros Klint and $\emptyset$ rsted Dal Members, and supplementary ammonite collections were made from the Vardekløft Formation. Triassic sediments, namely the pink arkoses of the Klitdal Member, directly overlie the granites of Liverpool Land. These arkoses were found to be unaffected by major faults, in contrast to Coe's (1971) observations in the same area. Generally the thickness of the Triassic layers here decreases southwards. The gypsum-bearing beds of the Solfaldsdal Member die out in a southerly direction $10 \mathrm{~km}$ north of $71^{\circ} \mathrm{N}$ in Klitdal, while those of the overlying Kap Seaforth Member continue to just south of $71^{\circ} \mathrm{N}$. The Klitdal Member extends farther south to Hurry Inlet. In the Kap Hope area, at the southern end of Liverpool Land, the down-faulted Triassic and Jurassic sediments described and mapped by Rosenkrantz (1942) were revisited. The sediments present can be attributed to the Triassic Klitdal and Ørsted Dal Members and the Jurassic Kap Stewart Formation and the Sortehat and Pelion Members.

In southern Jameson Land the mapping was continued west of a $10 \mathrm{~km}$ wide strip along Hurry Inlet mapped in 1970. The geology of this area, uninviting because vast areas are covered by vegetation or are poorly exposed, was practically unknown, the only information being an indication of loose blocks with Upper Jurassic fossils found at Aucellaelv (Spath, 1936; Donovan, 1964). However, the mapping unexpectedly revealed a complete Upper Jurassic sequence of Upper Oxfordian, Kimmeridgian and Portlandian age, dipping very slightly southwards. To the south these deposits are overlain unconformably by Lower Cretaceous deposits described by Aldinger (1935). A revised scheme of formations and members of this area will be introduced in a separate paper by Surlyk, Callomon, Bromley and Birkelund, in which the sequence is divided into (a) Hareelv Formation of Upper Oxfordian-Middle Kimmeridgian age, (b) Raukelv Formation of Upper Kimmeridgian-Portlandian age and (c) Hesteelv Formation of Berriasian (Ryazanian) age. On the basis of the fossil content the sequence can be correlated in detail with the Upper Jurassic-Lower Cretaceous sequence of Milne Land (Håkansson et al., 1971).

In the Kap Brewster area, the Tertiary sediments described by Hassan (1953) were mapped by K. Birkenmajer. 


\title{
References
}

Aldinger, H. 1935: Geologische Beobachtungen im Oberen Jura des Scoresbysundes (Ostgrönland). Meddr Grønland 99, 1, $128 \mathrm{pp}$.

Callomon, J. H. 1970: Geological map of Carlsberg Fjord-Fossilbjerget area. Meddr Grønland 168, 4, $10 \mathrm{pp}$.

Coe, K. 1971: Faulting in the western part of Liverpool Land, East Greenland. Bull. geol. Soc. Denmark 20, 260-264.

Donovan, D. T. 1964: Stratigraphy and ammonite fauna of the Volgian and Berriasian rocks of East Greenland. Meddr Gronland 154, 4, 34 pp.

Grasmüick, K. \& Trümpy, R. 1969: Triassic stratigraphy and general geology of the country around Fleming Fjord (East Greenland). Meddr Gronland 168, 2, I, 5-76.

Hassan, M. Y. 1953: Tertiary Faunas from Kap Brewster, East Greenland. Meddr Grønland $111,5,42 \mathrm{pp}$.

Håkansson, E., Birkelund, T., Heinberg, C. \& Willumsen, P. 1971: Preliminary results of mapping the Upper Jurassic and Lower Cretaceous sediments of Milne Land. Rapp. Gronlands geol. Unders. 37, 32-41.

Rosenkrantz, A. 1942: The Lower Jurassic rocks of East Greenland. Part II: The Mesozoic sediments of the Kap Hope area, southern Liverpool Land. Meddr Grønland 110, 2, 56 pp.

Spath, L. F. 1936: The Upper Jurassic invertebrate faunas of Cape Leslie, Milne Land. II. Upper Kimmeridgian and Portlandian. Meddr Grønland 99, 3, 180 pp.

Institut for historisk Geologi og Palæontologi,

University of Copenhagen,

Østervoldgade 10, 1350 Copenhagen $K$.

\section{AERORADIOMETRIC SURVEY IN THE SCORESBY SUND REGION, EAST GREENLAND}

\author{
Bjarne Leth Nielsen
}

Independent of the main East Greenland mapping project (see Henriksen, this report), an aeroradiometric survey was carried out in the Scoresby Sund region in July. Three areas were surveyed in detail: (a) the eastern part of Milne Land, (b) the southern part of Liverpool Land, east of Hurry Inlet and (c) west of the Schuchert Dal between Bjørnbo Gletscher and Ivar Baardsøn Gletscher. Furthermore, several reconnaissance flights were made over Jameson Land, in the Mestersvig area and to the north of Mestersvig as far as Loch Fyne.

\section{The equipment}

The aircraft used was a Dornier 28 with STOL capabilities operated at a slow cruising speed and at minimum ground clearance. The mean speed during radiometric sampling was $80 \mathrm{~m} . \mathrm{p} . \mathrm{h}$. at a ground clearance of about 150 feet. The detecting system mounted in the aircraft consisted of two $6 \times 4$ inches NaI (TI) 